\title{
IF HISTORY MATTERED: JOHN MARSHALL AND REFRAMING THE CONSTITUTION
}

\author{
Aviam Soifer* \\ John Marshall and the Heroic Age of the Supreme Court. \\ By $R$. Kent Newmyer. Baton Rouge: Louisiana State University Press. \\ 2001. Pp. xviii, 568. \$39.95.
}

What more can there be to learn about John Marshall?

We have been blessed recently with a flood of fine books about Marshall and the Supreme Court over which he presided from 1801 until $1835 .{ }^{1}$ We also now have readily available an impressive collection of documents concerning the Court before Marshall, as well as a fine series collecting, introducing, and annotating Marshall's papers. ${ }^{2}$ With recent bicentennial celebrations marking the beginning of Marshall's career as Chief Justice and the anniversary of Marbury $v$. Madison, ${ }^{3}$ an outpouring of law review articles and scholarly symposia have offered learned exchanges about the great Chief Justice and his most famous decision. ${ }^{4}$

It turns out, however, that Kent Newmyer's account of John Marshall and his times actually illuminates a vigorous current debate. We are witnessing a bitter fight within the Supreme Court over federalism, the relative weight to give constitutional text, and the basic

* Dean and Professor, William S. Richardson School of Law, University of Hawai'i. B.A. 1969, M.A. (Urban Studies) 1972, J.D. 1972, Yale. - Ed.

1. Jean EdWARd SMITH, John MARShall: Definer of a Nation (1996) is a fine biography that illuminates Marshall's personal life. HERBERT A. JOHNSON, THE CHIEF JUSTICESHIP OF JOHN MARSHALL, 1801-1835 (1997), and CHARLES F. HOBSON, THE GREAT CHIEF JUSTICE: JOHN MARSHALL AND THE RULE OF LAW (1996) offer many insights on law and legal doctrine. Two excellent Marshall Court volumes published in the $1980 \mathrm{~s}$ as part of the Oliver Wendell Holmes Devise History of the Supreme Court of the United States are invaluable. They are GEORGE LEE HASKINS AND HERBERT A. JOHNSON, FOUNDATIONS OF POWER: JOHN MARSHALL, 1801-1815 (1981), and G. EDWARD WHITE (with the aid of Gerald Gunther), The MARSHall COURT AND CUltural CHANGE, 18151835 (1988).

2. THE DOCUMENTARY HISTORY OF THE SUPREME COURT OF THE UNITED STATES, 1789-1800 (Maeva Marcus \& James R. Perry eds., 1985-1998) (6 vols. to date); THE PAPERS OF JOHN MARSHALL (Herbert A. Johnson et al. eds., 1974-2000) (11 vols. to date).

3. 5 U.S. (1 Cranch) 137 (1803).

4. See, e.g., Symposium, Marbury and lts Legacy, 71 GEO. WASH. L. REV. (forthcoming 2003); Symposium, Judging Judicial Review: Marbury in the Modern Era, 101 Mich. L. Rev. (forthcoming 2003).

5. Professor of Law and History, University of Connecticut School of Law. 
role of judges. ${ }^{6}$ In a manner that echoes the Court's internal divisions during the early 1930 s, current Justices repeatedly battle about what the founding generation meant to do in passing, ratifying, and beginning to interpret the Constitution.

Though Newmyer's excellent historical work is anything but "presentist," it turns out to be relevant as it clearly conveys the constitutional vision proclaimed by Marshall and his fellow Justices. This careful study directly contradicts the state sovereignty claims that have been made repeatedly by a majority of the current Court. Newmyer provides a cogent portrait of how John Marshall's charm and legal craftsmanship forged a vision of balanced federalism. With tenacious research and crisp writing, Newmyer demonstrates that Marshall was a committed nationalist, who nonetheless divided sovereignty, respected the states, and hoped to facilitate individual entrepreneurial efforts. Yet in service to an expansive national promise - a promise entailing a constitutional commitment that Marshall did not doubt the Framers shared - the Chief Justice repeatedly led his remarkably collegial Court to interpret Congress's powers broadly. He did so "to help Congress help the people help themselves build a nation" (p. 302).

John Marshall and the Heroic Age of the Supreme Court synthesizes Marshall's life and his lawyerly approach to a multitude of openended issues. Newmyer underscores the judicial work that Marshall and his fellow Justices "did best and most often, which was not making law wholesale but building incrementally through analogy, extrapolation, and matching principle to fact" (p. 288). Of all the writing about Marshall in recent years, Kent Newmyer's biography is the book most likely "to endure for ages to come."

\section{COMBINing LAW AND Politics, in A DifFERENT KeY}

Probably the best reason to enjoy reading and reflecting upon John Marshall and the Heroic Age of the Supreme Court concerns the book's central issue. Newmyer offers an insightful and often paradoxical analysis of how a largely eighteenth-century man worked to make the values of the American Revolution relevant to a new age (p. 271). Marshall chose to attend closely to the language and structure of the entire Constitution, while also focusing on practical concerns raised by the particular case under consideration. Marshall's Court also stands

6. See, e.g., Fed. Mar. Comm'n v. South Carolina Ports Auth, 535 U.S. 743 (2002); Bd. of Trs. of the Univ. of Ala. v. Garrett, 531 U.S. 356 (2001); United States v. Morrison, 529 U.S. $598(2000)$. 
apart because of his own remarkable, forward-looking approach to constitutional adjudication. ${ }^{8}$

Newmyer illuminates the role of judges such as Marshall who unabashedly functioned within the realms of both politics and law. Marshall and his colleagues intended to engage in republican governance through judicial decisionmaking. It was generally believed that the Constitution could not be understood without reference to the common law. Yet what role the common law should play remained strikingly imprecise. Often, in fact, intense debate about common law principles and appropriate jurisdiction became "the touchstone of party division and the focal point of ideological arguments over the meaning of republican government."

In contrast to the popular portrait of Marshall as an aggressive and committed nationalizer, however, Newmyer depicts a beleaguered champion of the federal union who sought and tried to hold the high middle ground mapped out by the Framers. If Newmyer may seem to puff slightly in labeling Marshall's time on the Court as "heroic," his book concentrates on how isolated Marshall and his Court were most of the time. Marshall's restraint nonetheless functioned as a key element of his many achievements. In this respect, as well as in myriad others, Marshall's entire approach to law and governance sharply contrasts with the judge-centered activism that dominates the Court today.

Marshall tended to trust government officials, for example. He "saw both judicial and congressional power in terms of eighteenthcentury deference, where the officials of government were expected to govern because they were presumed to be honest and able" (p. 353). In sharp contrast, the Supreme Court's current corrosive skepticism in regard to Congress, and even with reference to lower federal judges, actually evokes the vehement distrust of these same institutions prevalent among Marshall's most outspoken opponents, such as Spencer Roane of the Virginia Court of Appeals.

In Newmyer's account, Marshall combined law and politics with enthusiasm and flair. The law-and-politics combination served as an important element in Marshall's ongoing effort to follow a common law approach grounded in experience while aimed toward the future. This legal experimentation developed through Marshall's clear thinking and his striking way with words, as well as his personal charm and collegial-constitutional jurisprudence. Marshall and his fellow Justices

8. For insightful explication of this approach in McCulloch and other John Marshall opinions, see ChaRles L. BLACK, JR., THE PEOPLE AND THE COURT (1960) [hereinafter Black, The People], and Charles L. Black, Jr., Structure and Relationship in CONSTITUTIONAL LAW (1969).

9. R. KENT NEWMYER, SUPREME COURT JUSTICE JOSEPH StORY: STATESMAN OF THE REPUBLIC 98 (1985). 
envisioned a national government strong and energetic enough to promote the general welfare. They also were dedicated to protecting individual rights such as contract and, preeminently, property particularly against state legislatures, which they perceived to be the primary threat (pp. 271, 318-19).

Marshall, of course, had been directly involved - to the point of "consanguinity to the Framers" (p. 482) - in the ambitions and concerns of those who fought for independence and who went on to produce and ratify the Constitution. Before he even reached the Court, Marshall had been a Revolutionary War soldier and an aide to General George Washington; a distinguished Virginia lawyer and politician; a member of the Virginia ratifying convention who strongly favored the federal Constitution; a charming politician who broke ranks with his party, opposed the Alien and Sedition Acts, and got elected to Congress; a foreign diplomat celebrated for his role in the $\mathrm{XYZ}$ affair; and John Adams's Secretary of State (when that department was in charge of most of the federal government as well as international affairs) (pp. 1-145). It is thus hardly surprising that Marshall seemed to himself and many others to be extraordinarily wellpositioned to understand the Constitution.

As Chief Justice, Marshall liked to bolster his opinions by pointing out specific ways in which the Articles of Confederation launched a national government too weak to serve the interests of its citizens. By contrast, as the written manifestation of a grand national experiment, the Constitution "armed the agents of the 'American people' with real 'power" "(p. 309). Moreover, Marshall strongly believed that "[t]he Union was in danger from the states and from a persistent cultural localism, not the other way around" (p. 299).

Marshall and his colleagues were not shy about practicing their pioneering mixture of law and politics from the bench. For them, this also meant acknowledging that the Constitution could confine judges and that it required great deference to other branches of government (pp. 253, 282-83, 309-10). It was the will of the American people, expressed through the promises of the grand constitutional experiment, that they believed they had to vindicate. On the other hand, the American people spoke regularly through elections and the actions of their elected representatives in Congress and the Executive. Therefore, the Court would and could intervene only hesitantly and only when required to do so, with due regard to whether an intervention made practical, political sense. ${ }^{10}$

In contrast to current Supreme Court Justices, Marshall's direct experience in, and concern for, representative governance made him

10. See Maeva Marcus, Is the Supreme Court a Political Institution? (presented at Boston College Law School Legal History Workshop on Mar. 20, 2003) (unpublished manuscript, on file with author). 
quite deferential toward Congress and even toward the Executive. This was so even in the context of Marbury, despite Marshall's somewhat dubious holding as to the unconstitutionality of Section 13 of the Judiciary Act of 1789. Much of Marshall's compelling language in Marbury, and most of his remarkable strategic moves to get the Court out of an extremely tight political corner, ${ }^{11}$ suggest deference to the political branches in matters broadly defined as political. Yet, famously, once Marshall proclaimed there to be a clear line between political and legal matters within the Executive, he seemed to claim for the judiciary the authority to find that line. ${ }^{12}$ (It is noteworthy that the constitutional invalidation in Marbury stands alone. Not only was it the only time the Court struck down congressional action throughout Marshall's long tenure, but it also was the only invalidation by the Court from its inception until Dred Scott. $)^{13}$ The Court, having claimed the power to say "no," could thereafter actually legitimate Congress's discretionary calls by refusing to invalidate them. ${ }^{14}$ As Newmyer says of Marbury:

Some see the opinion as a victory of law over politics, others as supremely political, which leads one to wonder whether it was not, like the Constitution itself, both at once. Like a great work of art, Marbury yields different meanings to different viewers at different times - which may be the true mark of greatness. (p. 158)

11. In addition to Newmyer's well-textured treatment, see, for example, Susan Low Bloch \& Maeva Marcus, John Marshall's Selective Use of History, in Marbury v. Madison, 1986 WIS. L. REV. 301; Mark A. Graber, Establishing Judicial Review? Schooner Peggy and the Early Marshall Court, 51 POL. RES. Q. 221 (1998); and James M. O'Fallon, Marbury, 44 STAN. L. REv. 219 (1992). Senator Albert J. Beveridge was less precise in describing Marshall and his Supreme Court colleagues as "law-givers as well as law-expounders" in his lively four-volume biography, 3 ALBERT J. BEVERIDGE, THE LIFE OF JOHN MARSHALL 24 (1919), but he similarly stressed that there were many judicial precursors to Marbury.

12. Marbury v. Madison, 5 U.S. (1 Cranch) 137, 166-67 (1803). In Marbury, Marshall emphasized the need to protect the vested individual right whose existence he had abruptly just announced. Over and over in Marbury, he insisted that if a court had proper jurisdiction, the judges could not be blind to their legal obligation to provide a remedy when faced with a right. Indeed, Marshall proclaimed it to be an essential judicial duty to assure that government officials provide legal protection. The obligation imposed on a member of the Executive Branch to deliver a signed and sealed commission, for example, thus could be considered an encapsulation of the proper role for all government actors, including judges. Throughout his judicial career, Marshall insisted further that the Constitution guaranteed that the nation would act affirmatively to protect the rights of individuals. Thereby, the Constitution afforded new opportunities and produced the release of energy necessary for an expanding nation to fulfill its great promise.

13. Dred Scott v. Sanford, 60 U.S. (19 How.) 393 (1857).

14. As Marshall wrote in McCulloch v. Maryland:

But we think the sound construction of the constitution must allow to the national legislature that discretion, with respect to the means by which the powers it confers are ... carried into execution, which will enable that body to perform the high duties assigned to it, in the manner most beneficial to the people.

17 U.S. (4 Wheat.) 316, 421 (1819). See generally BLACK, THE PEOPLE, supra note 8. 
Much the same might be said about the Chief Justice himself, and Newmyer's book establishes a significant benchmark for judging judges. Different viewers at different times are sure to assess this book and its subject differently. Yet Newmyer's biography will remain significant if history matters when we judge judges and evaluate proclamations concerning the Constitution's spirit and the underlying postulates of federalism.

\section{Play in the Federalism Joints: A LitTle HistoriCAL FOUNDATION}

Somewhat grudgingly, Justice Oliver Wendell Holmes, Jr. once observed that Marshall's greatness lay primarily in being at the right place at the right time. In reference to Marshall, Holmes wrote: "A great man represents a great ganglion in the nerves of society, or, to vary the figure, a strategic point in the campaign of history, and part of his greatness consists in his being there." 15 It is important to note that Marshall wrote on a largely blank slate. ${ }^{16}$ That he had this advantage makes it more striking how often, as Newmyer points out repeatedly, Marshall's opinions tended to be relatively modest and to rest on some middle position rather than to endorse extremes.

This was so even in the Court's famous decisions that dealt with large and unsettled questions of the authority of the Supreme Court and the power of the federal government vis-à-vis the states. Ironically, for example, Marshall's last constitutional law decision was Barron v. Mayor and City of Baltimore. ${ }^{17}$ Newmyer convincingly argues that this particular concession to state power by Marshall "reminds one, as it must have reminded contemporaries, that his

15. Oliver Wendell Holmes, John Marshall: In Answer to a Motion that the Court Adjourn, on February 4, 1901, the One Hundredth Anniversary of the Day on which Marshall Took His Seat as Chief Justice, reprinted in JAMES BRADLEY THAYER ET AL., ON JOHN MARSHALL 129, 131 (1967). Holmes went on to concede, seemingly with a tint of jealousy, that:

there fell to Marshall perhaps the greatest place that ever was filled by a judge; but when I consider his might, his justice, and his wisdom, I do fully believe that if American law were to be represented by a single figure, sceptic and worshipper alike would agree without dispute that the figure could be but one alone, and that one John Marshall.

Id. at 133. One hundred years later, $\mathrm{C}$. Edward White offered an intriguing analysis of this Holmes-Marshall connection in G. Edward White, Looking at Holmes Looking at Marshall, 7 MASS. LEGAL HIST. 63 (2001).

16. Marshall liked to rely on established practice, however, as he did for example with powerful rhetorical effect in McCulloch, 17 U.S. (4 Wheat.) at 402, 422-23 (emphasizing the repeated use and chartering of national banks by Jeffersonians as well as by Federalists). Nonetheless, when precedents and practice pointed in an inconvenient direction, Marshall was not above ignoring them - or constructing a useful hypothetical case out of elements of past decisions less helpful for his purposes. See Bloch \& Marcus, stupra note 11, at 311-20.

17. 32 U.S. (7 Pet.) 243 (1833) (holding that individual property owner had no federal rights claim because the federal Bill of Rights did not apply to the states). 
nationalism had considerable states' rights play in the joints and that his federalism, like that of the Framers, was rooted in historical reality" (p. 435).

It would be a serious mistake to overlook the bona fide logical, textual, and historical arguments Marshall both internalized and liked to claim in support of his views about what the Constitution was meant to do. Being faithful to what the people had wrought and furthering the promise of the Revolution became matters of overriding importance in his hands. One did not have to be religious (Marshall apparently was not) to feel something akin to faith about such matters. As Newmyer earlier wrote of Joseph Story, whose contact with the Revolutionary War was much less direct than Marshall's: "To those like Story whose lives it touched the Revolution was a miracle, a sign of God's grace, a reminder of the covenant."18 Even more than Story, Marshall set out to make the promise and the idealism of that Revolution a permanent part of America's legal and political landscape.

State legislatures "embodied the worst features of the new democratic political order" (p. 145) for Marshall. Proponents of states' rights, most notably Thomas Jefferson but also a majority of Marshall's friends at the Virginia bar, failed to recall the many ways in which state sovereignty actually had interfered with the Revolutionary War effort and now could endanger the peace. Perhaps worse - as Marshall proclaimed as early as his 1788 debate with Patrick Henry over whether Virginia should ratify the Constitution - state sovereignty exemplified in the Articles of Confederation clearly stripped the nation of the "energy" necessary "to protect the United States, and to promote the general welfare."19

\section{THE LION IN WINTER}

By the 1820s, Marshall was fighting a rear-guard action. Newmyer notes that the shift in constitutional law usually associated with the Taney Court in 1837 "really began in the final years of Marshall's tenure and to some extent with his compliance" (p. 412). Marshall was conflicted over what he tragically perceived as a division between morality and law regarding the slave trade (pp. 426-34). He also was both creative and inconsistent as he wrestled with the legal status of American Indians and the awful Cherokee removal policy (pp. 44058). After the state of Georgia directly defied the Supreme Court by executing a Cherokee named Corn Tassel in late 1830 (though the Court had issued and Marshall had signed a writ of habeas corpus on 
his behalf), Marshall began to develop a new category for Indian tribes: "domestic dependent nations" (pp. 450-57). He then insisted in Worcester v. Georgia that the tribes retained sufficient sovereignty to make treaties with the federal government, yet also that "a weaker power does not surrender its independence - its right to selfgovernment, by associating with a stronger and taking its protection." ${ }^{20}$ Sadly, Marshall's opinions entirely failed to protect the Cherokee. Yet Newmyer maintains that Marshall's determination to uphold federaltreaty obligations to protect the Cherokee against state depredations - even if his opinions emphasized "the actual state of things" and required "ramshackle functionalism" in what proved to be a losing struggle - might have been the "finest moment" for a valiant "old soldier of republicanism" (pp. 457-58).

Newmyer's extraordinary final chapter offers an intriguing historiography of the Marshall myth as well as a compelling argument for the many ways in which the "real" John Marshall truly was impressive. Marshall forged the Court's role out of personal charm and analytic and verbal brilliance. He built doctrines from experience, custom, and history. As Newmyer points out in the course of his luminous, bittersweet Epilogue - in which he ruminates provocatively about John Marshall, the Court, and constitutional law - the Constitution was "the supreme law of the land, as Article 6 proclaims, and a bundle of political compromises" (p. 483). Nationalist commitments were superimposed on a culture that was primarily local, and that remained that way for many years.

Though Marshall was hardly a "status quo conservative," he believed that the contours of the Constitution actually did confine judicial discretion (pp. 253, 481-82). This was generally satisfactory for Marshall, in Newmyer's view, because "[t]he Framers took on state sovereignty, as the ratifying debates conclusively show, and Marshall followed their lead" (p. 483). Yet during his final years, Marshall felt he had lost the key battle over federalism. And Newmyer agrees that Marshall wound up "on the losing side of antebellum history" (p. 484). Though Marshall did a great deal to put the Court at the center of constitutional debate, "Jefferson and Jackson taught [him] ... that the Court does not have the final word on the Constitution" (p. 484).

\section{Construing a CONSTITUtion V. GRASPing AT EsSEntial POSTULATES}

To appreciate John Marshall's general approach is to realize how different and radically activist the current Court now delights in being. 
Neither this Court's startling disrespect for Congress ${ }^{21}$ nor its aggressive interventions in the name of the dignity of the states can even begin to compute - as it were - with the constitutional promises Marshall tried to anchor in context. Even when current Justices purport to be limited by common law principles, moreover, they generally endorse a parsimonious view of these principles, quite inconsistent with what the common law embodied for John Marshall, who was surely one of the nation's greatest common law lawyers and judges. $^{22}$

In construing the common law, Marshall differed significantly from his friend and colleague, Justice Joseph Story. As Newmyer's earlier monumental biography of Story makes clear, the much more scholarly Story emphasized the past and sought to develop theoretically pure, scientific principles for common law interpretation. ${ }^{23}$ By contrast, Marshall brought to judging a frontiersman's strong preference for common sense over theory (p. 15). Indeed, he willingly, even enthusi-

21. See, e.g., Ruth Colker \& James J. Brudney, Dissing Congress, $100 \mathrm{MICH}$. L. REV. 80 (2001); Jed Handelsman Shugerman, Marbury and Judicial Deference: The Shadow of Whittington v. Polk and the Maryland Judiciary Battle, 5 U. PA. J. ConsT. L. 58, 61 (2002) (mentioning thirty-three decisions striking down acts of Congress in seven year period from 1995 2002, constituting one-sixth of entire set of such decisions from the nation's Founding). This count does not include the many decisions reflecting the Justices' penchant for narrowing federal statutes into oblivion, as in the remarkably crabbed reading of the Americans with Disabilities Act. See, for example, cases discussed in Larry D. Kramer, The Supreme Court 2000 Term - Foreword: We the Court, 115 HARv. L. REv. 4 (2000); Aviam Soifer, The Disability Term: Dignity, Default, and Negative Capability, 47 UCLA L. REV. 1279 (2000); and Aviam Soifer, Disabling the ADA: Essences, Better Angels, and Unprincipled Neutrality Claims, 44 WM. \& MARY L. REV. 1285 (2003). See generally JOHN T. NOONAN, JR., NARROWING THE NATION'S POWER: THE SUPREME COURT Sides WITH THE STATES (2002).

22. This has been particularly so in the realm of family law and individual autonomy. The Court repeatedly has conceded the relevance of substantive due process, but then interpreted constitutional rights narrowly in the name of common law limitations. See, e.g., Washington v. Glucksberg, 521 U.S. 702 (1997) (emphasizing common law rules against suicide); Cruzan v. Missouri Dep't of Health, 491 U.S. 261 (1990) (pointing to long common law tradition in support of Missouri's rule forbidding discontinuance of life-sustaining medical procedures); Michael H. v. Gerald D., 497 U.S. 110 (1989) (stressing "history and tradition," anchored in the common law, as basis to reject due process claims of biological father seeking contact with daughter). On the other hand, Newmyer points out that "the law Marshall practiced was traditional[ist] and instrumentalist at the same time. It was deeply indebted to the common law for both method and doctrine. It was also instrumentalist as the common law had in fact always been. ... Practicing law was, or could be, a form of governance." P. 101-02. In the common law tradition that Marshall embodied, "It was not just a matter of judicial review, but rather the entire institutional and intellectual apparatus of judicial deliberation that was relevant." P. 208. Marshall believed that there were "true" legal answers, but he also understood keenly both the importance of facts and the Court's vulnerabilities.

Justice Kennedy's evolutionary theory regarding liberty claims articulated in Lawrence v. Texas, 123 S. Ct. 2472 (2003), is much closer to Marshall's approach, as is Justice Souter's effort to approach constitutional law cases with a mode of common law reasoning in Glucksberg, 521 U.S. at 767 (Souter, J., concurring), and $C$ \& $A$ Carbone v. Clarkston, 511 U.S. 383, 424 (1994) (Souter, J., dissenting). 
astically, used common law as a means to envision and to shape the future, rather than as a binding constraint imposed by the past.

Marshall's constitutional opinions concentrated on interpreting the language of the Constitution in context. ${ }^{24} \mathrm{With}$ great phrasing and considerable élan, Marshall also proclaimed which issues of construction were open and which had been foreclosed by practice. Constitutional answers might be sought through Marshall's identification of (and with) the thoughts and dreams of the Framers, by consideration of established practices after the Constitution was ratified, and by the demands of the future. In his great McCulloch $v$. Maryland opinion, for example, Marshall asserted that the first question he posed - "has Congress power to incorporate a bank?" - could in actuality "scarcely be considered as an open question." 25 Political acceptance of a national bank over time had validated Congress's power. Even those such as James Madison, for example, who once vigorously opposed this national power, had come to appreciate the need for the Bank and for such power.

Later in McCulloch, however, Marshall maintained that "the question respecting the extent of the powers actually granted [to the national government], is perpetually arising, and will probably continue to arise, as long as our system shall exist." ${ }^{.26}$ Marshall was certain that the American people, through the Constitution they had created for themselves, guaranteed the national government all the broad powers necessary and proper to promote the general welfare as future needs arose across the length and breadth of the continent. ${ }^{27}$

Paradoxically, Marshall's very temerity in invoking law by looking to the future allowed him to appear to offer potential restraint through the Court's authority and its specific holdings. Marshall maneuvered

24. Pp. 226, 253, 288, 302, 316. In his massive study of the Marshall Court, Ted White summarized Marshall's technique as follows: "In each of the great constitutional cases that came before the Marshall Court a critical word or group of words in the Constitution's text was recast through [linguistic analysis], converted into a principle, and made applicable to a situation not explicitly contemplated by the Framers." WHITE, 1815-35, supra note 1, at 8 . The current Court, by contrast, explicitly deprecates context in its proclaimed faith in text, see, e.g., Alexander v. Sandoval, 532 U.S. 275 (2001), but it also is willing to base its federalism decisions in its perception of "essential postulates," for example, or in some underlying or overarching sense of the spirit of the Constitution requiring no anchor in the text. See, e.g., Fed. Mar. Comm'n v. South Carolina Ports Auth., 535 U.S. 743 (2002); United States v. Morrison, 529 U.S. 598 (2000); Alden v. Maine, 527 U.S. 706 (1999).

25. 17 U.S. (4 Wheat.) 316, 401 (1819).

26. McCulloch, 17 U.S. ( 4 Wheat.) at 405.

27. McCulloch may be the best single source for this view, which is a central theme of Newmyer's book. For Marshall, the Necessary and Proper Clause in Article I, Section 8 clearly was meant to grant broad national powers to Congress and thereby to cure the central ills of the Articles of Confederation. By contrast, for example, writing for the majority in Printz v. United States, 521 U.S. 898 (1997), Justice Scalia denigrated the Necessary and Proper Clause as "the last, best hope of those who defend ultra vires congressional action." Id. at 923. 
masterfully to find ways to balance between his own open, and even sweeping language and what frequently turned out to be the quite narrow actual results of his decisions. ${ }^{28}$ Marshall benefited from the fact that what constituted relevant sources or traditions was not at all clear; indeed, many of the still very small number of Supreme Court precedents had not been reliably reported. Nonetheless, he exploited this unusual judicial freedom with considerable caution. By contrast, the current Court's sweeping theoretical views erase precedents and history with abandon. Today, the Court seems to have little respect for either the wisdom of the ages, or for contemporary results of national democratic processes.

\section{CONCLUSION}

Newmyer ends his fine book by stressing how much Marshall's name and ideas still command attention on a daily basis "in the actual work of the Court as it serves the American nation he loved" (p. 485). In this regard, however, Newmyer may be betraying his own Midwestern optimism. In fact, Marshall and his opinions are being badly used and abused by the current Court.

Instead of deference or even respectful consideration of the work of Congress, for example, today we have ringing proclamations of the Court's exclusive power. ${ }^{29}$ These tend to occur within decisions in furtherance of states' rights abstractions, at times undeterred even when a substantial majority of the states reject the very claims made

28. Marbury is a famous example of judicial authority through indirection, but there are many more within Marshall's work product. Gibbons v. Ogden, 22 U.S. (9 Wheat.) 1 (1824), for instance, is a great Commerce Clause case in which Marshall "knew that indeterminacy had its uses, which is to say he pushed nationalism only as far as the moment allowed but not further." P. 314. For other examples of Marshall's deference to state powers, see, for example, Providence Bank v. Billings, 29 U.S. (4 Pet.) 561 (1830) (rejecting claim of implied immunity from state taxation in a bank charter), and Willson v. Black Bird Creek Marsh Co., 27 U.S. (2 Pet.) 245 (1829) (holding that Delaware law authorizing a dam across navigable creek was not repugnant to Congress's dormant commerce power). Unaccountably, Newmyer mentions a bridge in discussing this case, rather than a dam. P. 410. This appears to be an extremely rare factual error in a book that is stuffed with facts. Yet, it must be said that there are an unusual number of nettlesome typographical errors.

Even Marshall's indeterminacy hardly lends support to Justice Thomas's radical rereading of both Gibbons and the relevant history of the Commerce Clause. See, e.g., Camps Newfound/Owatonna, Inc. v. Town of Harrison, 520 U.S. 564, 610-40 (1997) (Thomas, J., concurring) (rejecting negative Commerce Clause approach altogether); Printz v. United States, 521 U.S. 898, 937 (1997) (Thomas, J., concurring) (accepting that his view is "revisionist" but arguing that Commerce Clause power does not extend to regulation of wholly intrastate, point-of-sale transactions); United States v. Lopez, 514 U.S. 549, 593-96 (1995) (Thomas, J., concurring) (rejecting "substantial effects" on interstate commerce as sufficient basis for congressional regulation).

29. See, e.g., Morrison, 529 U.S. at 616 n.7 ("[E]ver since Marbury this Court has remained the ultimate expositor of the constitutional text."); Kimel v. Florida Bd. of Regents, 528 U.S. 62, 81 (2000) ("The ultimate interpretation and determination of the Fourteenth Amendment's substantive meaning remains the province of the Judicial Branch."). 
on their behalf. ${ }^{30}$ Moreover, rather than considering history, customs, and context in defining the constitutional position of Native Americans, Aleuts, and Native Hawaiians, for example, the Court pursues a rigid either/or approach to claims of sovereignty regarding not only federalism, but also in determining the status of native rights. ${ }^{31}$ Further, the Court now stands Marbury's crucial right/remedy connection directly on its head in its pursuit of a historically unsupportable use of the Eleventh Amendment to protect states from perceived financial or dignitary harms. ${ }^{32}$ The contrast with John Marshall's sense of the Constitution, law, and the role of judges could scarcely be more dramatic.

There is a final reason to read Kent Newmyer's persuasive account of John Marshall and his legal world. One comes away somewhat reassured that judging by means of false dichotomies is hardly inevitable. Common sense and craftsmanship, respect for complexity as well as sensitivity to context also may make judicial opinions noteworthy.

Newmyer's nuanced portrait of a remarkable judge and of his extraordinary times, neatly done in dark colors with many shades of gray, makes this book so compelling. Indeed, it is a "must read" for anyone seeking to understand our basic constitutional-law-origin stories. Even if the current Court at times seems downright cynical about history, text, and context, John Marshall was not. Nor, to our great advantage, is Kent Newmyer. His book enacts many of John Marshall's best qualities, and it does so with clarity and verve.

30. Morrison, 529 U.S. at 654 (Souter, J., dissenting) (quoting R. JACKSON, THE STRUGGLE FOR JUDICIAL SUPREMACY 160 (1941)):

The collective opinion of state officials that the Act was needed continues virtually unchanged, and when the Civil Rights Remedy was challenged in court, the States came to its defense. Thirty-six of them and the Commonwealth of Puerto Rico have filed an amicus brief in support of petitioners in these cases, and only one State has taken respondents' side. It is, then, not the least irony of these cases that the States will be forced to enjoy the new federalism whether they want it or not. For with the Court's decision today, Antonio Morrison, like Carter Coal's James Carter, before him, has "won the states" rights plea against the states themselves.

31. See, e.g., Rice v. Cayetano, 528 U.S. 495 (2000) (holding that special election for Hawai'i Office of Hawaiian Affairs could not be restricted to Native Hawaiians, because category served as surrogate for racial discrimination in violation of Fifteenth Amendment); Blatchford v. Native Vill. of Noatak, 501 U.S. 775 (1991) (holding that Native Alaskan village is analogous to foreign nation, and therefore barred from suing state because of Eleventh Amendment); Joseph William Singer, Canons of Conquest: The Supreme Court's Attack on Tribal Sovereignty, 37 NEW ENG. L. REV. 641 (2003).

32. See, e.g., Bd. of Trs. of the Univ. of Ala. v. Garrett, 531 U.S. 356 (2001); Alden v. Maine, 527 U.S. 706 (1999). But see Jonathan ORTH, THE JudiCial POWER OF THE United States: The EleVENTH AMENDMENT in AMERICAN History (1987) (detailing frequent abuse of the language and context of the amendment over time); Maeva Marcus \& Natalie Wexler, Suits Against States: Diversity of Opinion in the 1790s, 1993 J. SUP. CT. HIST. 73 (debunking myth of national outrage after decision in Chisholm v. Georgia, 2 U.S. (2 Dall.) 419 (1793), and demonstrating inconsistency of the Court's recent Eleventh Amendment interpretations with history of the amendment's context, drafting, and passage). 